\title{
Hydraulic Conductivity of Compacted Laterite Treated with Iron Ore Tailings
}

\author{
Umar Sa'eed Yusuf, ${ }^{1}$ Matawal Danladi Slim, ${ }^{2}$ and Elinwa Augustine Uchechukwu' \\ ${ }^{1}$ Department of Civil Engineering, Abubakar Tafawa Balewa University, Bauchi 740001, Nigeria \\ ${ }^{2}$ Nigerian Building and Road Research Institute (NBRRI), Abuja 900001, Nigeria \\ Correspondence should be addressed to Umar Sa’eed Yusuf; umarsyusuf@yahoo.com
}

Received 14 November 2015; Revised 1 March 2016; Accepted 20 April 2016

Academic Editor: Kirk Hatfield

Copyright (c) 2016 Umar Sa'eed Yusuf et al. This is an open access article distributed under the Creative Commons Attribution License, which permits unrestricted use, distribution, and reproduction in any medium, provided the original work is properly cited.

\begin{abstract}
The objective of this study was to investigate the effect of iron ore tailings (IOT) on hydraulic conductivity of compacted laterite. The IOT conforms to ASTM C 618-15 Type F designations. In the present study, soil was admixed with 0-20\% IOT and compacted at moulding water content ranging from 10 to $25 \%$ using four types of compactive efforts. Hydraulic conductivities of the compacted soil-IOT mixtures were determined using deionized water and municipal solid waste leachate as the permeant fluids, respectively. Deionized water was the reference permeant fluid. Results of this study showed that hydraulic conductivity decreased with increase in IOT content as a result of improvement in mechanical properties of the soil. Permeation of the soil-IOT mixtures with leachate caused the hydraulic conductivity to drop to less than $1 \times 10^{-9} \mathrm{~m} / \mathrm{s}$ especially at higher compactive efforts. Also, bioclogging of the soil pores due to accumulation of biomass from bacteria and yeast present in the leachate tends to significantly reduce the hydraulic conductivity. From an economic point of view, it has been found from the results of this study that soil specimens treated with up to $20 \%$ IOT and compacted at the British Standard Light (BSL) compactive effort met the maximum regulatory hydraulic conductivity of less than or equal to $1 \times 10^{-9} \mathrm{~m} / \mathrm{s}$ for hydraulic barrier system.
\end{abstract}

\section{Introduction}

Guidelines have been compiled for selecting appropriate soil properties and compaction methods that are likely to result in low hydraulic conductivity of liners and covers $[1,2]$. These guidelines are based on experience and generally include minimum values or acceptable ranges for properties that describe composition of soil (e.g., Atterberg limits, particle size distribution) [3]. The primary function of liner in a landfill is to prevent the release of contaminants from the unit into the adjoining soil and therefore hydraulic conductivity should be as low as less than $1 \times 10^{-9} \mathrm{~m} / \mathrm{s}$ to be effective in the containment of municipal solid waste [4]. Borgadi et al. [5] have noted in their work that hydraulic conductivity is the basic parameter for design and characterization of landfill performance and reliability.

Material selection for landfill construction is usually based on local availability and many different soil types. Soil barriers containing appreciable clay minerals are materials used extensively in constructing liners and covers for waste containment units due to their low hydraulic conductivity. Rowe et al. [6] stated that undisturbed clayey barriers have a long record of performance with respect to the containment of chemical species often found in a waste disposal site. However, large cracks can occur in wet, compacted clays that are allowed to dry [7]. For this reason, it is necessary to investigate the engineering properties of compacted lateriteIOT mixtures for liner in hydraulic barrier system. Compacted laterite soil has been shown to possess good hydraulic conductivity and low shrinkage [8].

Yellishetty and Mudd [9] reported that iron is an abundant element in the earth crust averaging from 2 to $3 \%$ in sedimentary rocks to $8.5 \%$ in basalt and gabbro. Over 300 minerals contain iron but five are the primary sources of iron ore minerals: magnetite, goethite, hematite, siderite, and pyrite. Proper disposal of tailings arising from iron ore production has become crucial for the environmental preservation, causing the need to develop mechanism to 
TABLe 1: Particle size analysis results of the laterite.

\begin{tabular}{lc}
\hline Particle size $(\mathrm{mm})$ & Percentage passing $(\%)$ \\
\hline 3.35 & 100.0 \\
2.00 & 99.2 \\
1.18 & 96.4 \\
0.60 & 90.4 \\
0.30 & 79.8 \\
0.015 & 68.4 \\
0.075 & 48.7 \\
0.050 & 42.1 \\
0.035 & 38.8 \\
0.025 & 36.0 \\
0.018 & 34.0 \\
0.013 & 31.1 \\
0.010 & 29.1 \\
0.007 & 27.6 \\
0.005 & 24.4 \\
0.004 & 19.6 \\
0.003 & 16.4 \\
0.002 & 9.4 \\
\hline
\end{tabular}

reduce the costs involved in this activity [10]. Yellishetty et al. [10] investigated the possibility of recycling tailings from concentration of iron ore for the production of concrete and building brick ceramics. Several research groups have studied the effect of industrial wastes such as blast furnace slag, tincal ore waste, foundry green sand, paper mill sludge, and tire waste on the hydraulic conductivity of liner and cover systems for containment of solid wastes [11-14].

The primary objective of this study was to investigate the effect of IOT on hydraulic properties of laterite compacted using four different types of compaction energies. Hydraulic conductivity of soil-IOT mixtures was determined using two types of permeant fluids: (1) deionized water and (2) municipal solid waste (MSW) leachate. Deionized water was the reference permeant fluid.

\section{Characterization of Materials}

2.1. Laterite. The soil sample used for this study was obtained from a site in Bauchi, Nigeria, by method of disturbed sampling. The silica-sesquioxide ratio of the soil was 1.21 suggesting that it is laterite. The soil could be classified as moderately plastic clay type A-6 in accordance with American Association of State Highway Transportation Officials (AASHTO M 145) [15] and CL in accordance with American Society for Testing and Materials (ASTM D 2487) [16]. The particle size distribution and the physical properties of the soil are summarized in Tables 1 and 2, respectively. The oxide compositions of the soil were determined by the X-ray fluorescence (XRF) spectroscopy method at the National Steel Raw Materials Exploration Agency (NSRMEA) in Kaduna and presented in Table 3.
TABle 2: Physical properties of the laterite.

\begin{tabular}{lc}
\hline Soil properties & Values \\
\hline Percentage passing $75 \mu \mathrm{m}$ sieve & 49 \\
Natural moisture content (\%) & 5 \\
Liquid limit (\%) & 38 \\
Plastic limit (\%) & 22 \\
Plasticity index (\%) & 16 \\
Linear shrinkage (\%) & 12 \\
Plasticity product & 143 \\
Specific gravity & 2.4 \\
AASHTO classification & $\mathrm{A}-6$ \\
ASTM classification & $\mathrm{CL}$ \\
Group index & 29 \\
Silica-sesquioxide molar ratio of iron and aluminum & 1.21 \\
\hline
\end{tabular}

TABLE 3: Chemical composition of the laterite.

\begin{tabular}{lc}
\hline Property & Concentration (\%) \\
\hline $\mathrm{Al}_{2} \mathrm{O}_{3}$ & 12.5 \\
$\mathrm{SiO}_{2}$ & 44.7 \\
$\mathrm{~K}_{2} \mathrm{O}$ & 8.1 \\
$\mathrm{CaO}$ & 2.3 \\
$\mathrm{TiO}_{2}$ & 2.2 \\
$\mathrm{~V}_{2} \mathrm{O}_{3}$ & 0.1 \\
$\mathrm{MnO}$ & 0.2 \\
$\mathrm{Fe}_{2} \mathrm{O}_{3}$ & 24.4 \\
$\mathrm{CuO}$ & 0.1 \\
$\mathrm{ZnO}_{\mathrm{Au}} \mathrm{O}_{3}$ & 0.1 \\
$\mathrm{ReO}^{\mathrm{NO}}$ & 3.6 \\
$\mathrm{UO}_{2}$ & 0.5 \\
$\mathrm{Total}$ & 0.4 \\
\hline
\end{tabular}

2.2. Iron Ore Tailings. The iron ore tailings (IOT) used in this study were sourced from Itakpe in Ajaokuta, Kogi state, Nigeria. The Itakpe Iron Mining Project is a ferruginous quartzite deposit of geological reserve amounting to 200 million tons and was established in 1971 to exploit the iron ore deposit. In the National Iron Ore Mining Project (NIOMP), Itakpe was designed to supply 2.155 million tons per year of 63-64\% iron (Fe) grade super concentrate to Ajaokuta Steel Company Limited and 550,000 tons per year of 67-68\% super concentrates to Delta Steel Company Limited, Aladja, Warri. The stripping ratio (waste/ore ratio) of the deposit would amount to approximately 28 million tons [17]. The IOT was ground and sieved using sieve size of $425 \mu \mathrm{m}$ for the physical and chemical properties shown in Table 4 . The IOT conforms to ASTM C 618-15 [18] Type F designation.

2.3. Municipal Solid Waste Leachate. The municipal solid waste (MSW) was collected during the dry season of the year from an active open dumpsite in Yelwa, Bauchi. The MSW was used to prepare the leachate used for this study and the chemical compositions of the leachate were determined by 
TABle 4: Physical and chemical characteristics of iron ore tailings.

\begin{tabular}{lc}
\hline Characteristics & Concentration \\
\hline Moisture content $(\%)$ & 0.22 \\
Bulk density $\left(\mathrm{Mg} / \mathrm{m}^{3}\right)$ & 1.65 \\
Specific gravity & 3.5 \\
$\mathrm{pH}$ & 13.1 \\
$\mathrm{Al}_{2} \mathrm{O}_{3}(\%)$ & $\mathrm{ND}$ \\
$\mathrm{SiO}_{2}(\%)$ & 20.2 \\
$\mathrm{~K}_{2} \mathrm{O}(\%)$ & 0.30 \\
$\mathrm{CaO}(\%)$ & 0.53 \\
$\mathrm{TiO}_{2}(\%)$ & 0.18 \\
$\mathrm{~V}_{2} \mathrm{O}(\%)$ & 0.02 \\
$\left.\mathrm{MnO}^{2} \%\right)$ & 0.05 \\
$\mathrm{Fe}_{2} \mathrm{O}_{3}(\%)$ & 76.84 \\
$\mathrm{Au}_{2} \mathrm{O}(\%)$ & 1.88 \\
\hline
\end{tabular}

ND: not detected.

TABLE 5: Physical and chemical properties of the leachate.

\begin{tabular}{lc}
\hline Parameter & Concentration \\
\hline $\mathrm{pH}$ & 7.8 \\
Biochemical oxygen demand $\left(\mathrm{BOD}_{5}\right)$ & 39.3 \\
Chemical oxygen demand (COD) & 136 \\
BOD $_{5} / \mathrm{COD}(\mathrm{ratio})$ & 0.29 \\
Calcium, Ca (mg/L) & 375 \\
Lead, $\mathrm{Pb}(\mathrm{mg} / \mathrm{L})$ & 0.02 \\
Copper, $\mathrm{Cu}(\mathrm{mg} / \mathrm{L})$ & 0.17 \\
Manganese, Mn (mg/L) & 29.0 \\
Zinc, $\mathrm{Zn}(\mathrm{mg} / \mathrm{L})$ & 5.04 \\
Chromium, Cr (mg/L) & 0.05 \\
Nickel, $\mathrm{Ni}(\mathrm{mg} / \mathrm{L})$ & 0.36 \\
Sodium, $\mathrm{Na}(\mathrm{mg} / \mathrm{L})$ & 33 \\
Magnesium, Mg (mg/L) & 113 \\
Potassium, K (mg/L) & 120 \\
Iron, Fe (mg/L) & 80 \\
Cadmium, Cd (mg/L) & 0.02 \\
\hline
\end{tabular}

means of the atomic absorption spectrophotometer (AAS) at the Public Health Engineering Laboratory in Abubakar Tafawa Balewa University, Bauchi. The organic content of the leachate sample was estimated by measuring the biochemical oxygen demand $\left(\mathrm{BOD}_{5}\right)$ and the chemical oxygen demand (COD). Table 5 summarizes the physical and chemical properties of the MSW leachate.

\section{Methodology}

3.1. Determination of Optimum Moisture Content and Maximum Dry Density. In carrying out tests on compaction, the soil was air dried in the laboratory and pulverized to sizes small enough to pass through US number 4 sieve $(4.76 \mathrm{~mm}$ aperture) in accordance with the procedure outlined in Head [19]. Five mixes were used and derived by adding $0 \%, 5 \%$,
$10 \%, 15 \%$, and $20 \%$ IOT to the soil. The control mix contains only the soil material while the remaining four mixes were prepared by adding 5-20\% IOT to the soil. Soil specimens were prepared using seven moulding water contents ranging from 10 to $25 \%$ by weight of the soil and compacted using the Reduced British Standard Light (RBSL), British Standard Light (BSL), West African Standard (WAS), and British Standard Heavy (BSH) compactive efforts, respectively. The RBSL (reduced proctor) and BSL (standard proctor) compaction utilized 15 and 27 blows, respectively, each of the $2.5 \mathrm{~kg}$ rammer falling freely from a height of $300 \mathrm{~mm}$ onto 3 layers in a $1000 \mathrm{~cm}^{3}$ mould. The WAS compactive effort utilized 10 blows of the $4.5 \mathrm{~kg}$ rammer falling freely through a height of $450 \mathrm{~mm}$ onto five equal layers of the soil in a $1000 \mathrm{~cm}^{3}$ mould. The WAS compactive effort is the conventional energy level commonly used in this region. The $\mathrm{BSH}$ or modified proctor compactive effort utilized 27 blows of the $4.5 \mathrm{~kg}$ rammer falling freely from a height of $450 \mathrm{~mm}$ onto 5 layers of the soil in a $1000 \mathrm{~cm}^{3}$ mould. Three samples were prepared for each percentage addition of IOT and the average optimum moisture contents (OMCs) and maximum dry densities (MDDs) taken. A total of 45 specimens were prepared for determination of moisture-density relationships of the soilIOT mixtures.

3.2. Determination of Hydraulic Conductivity. Figure 1 is the experimental setup used for hydraulic conductivity tests. It is the rigid-wall falling-head permeameter apparatus. The specimens for the hydraulic conductivity tests were prepared by adding IOT to the soil in proportions of $0 \%, 5 \%, 10 \%$, $15 \%$, and $20 \%$, respectively, as was the case for the compaction tests. The OMCs obtained from the moisture-density relationships and increased by $2 \%$ were used in accordance with the recommendation of USEPA [20]. In carrying out the tests, laterite soil was air-dried in the laboratory and pulverized to sizes small enough to pass US number 4 sieve ( $4.76 \mathrm{~mm}$ aperture). Five mixes were used and compacted using the RBSL, BSL, WAS, and BSH compactive efforts, respectively. The compacted soil specimens and mould for each addition of IOT were first placed in plastic immersion tanks and distilled water was introduced such that the top of the compacted soils was covered with $5 \mathrm{~cm}$ of water. Immersion of the compacted soil specimen and the mould in distilled water was to prevent drying of the specimens from lower open end of the mould. The setup was left to stand for 24 hours to achieve full saturation of the soil.

After the immersion period, distilled water level in the immersion tank was reduced and the entire falling-head setup was assembled in preparation for permeation. Permeation was carried out using deionized water and leachate as the permeant fluids, respectively. Permeation was terminated within 24 hours from the commencement of the test when the inflow is approximately equal to the outflow. Equilibrium was established when there was no significant trend in the standpipe readings during testing. The geometric mean of the last three readings was computed and reported as the hydraulic conductivity. A total of 120 specimens were 


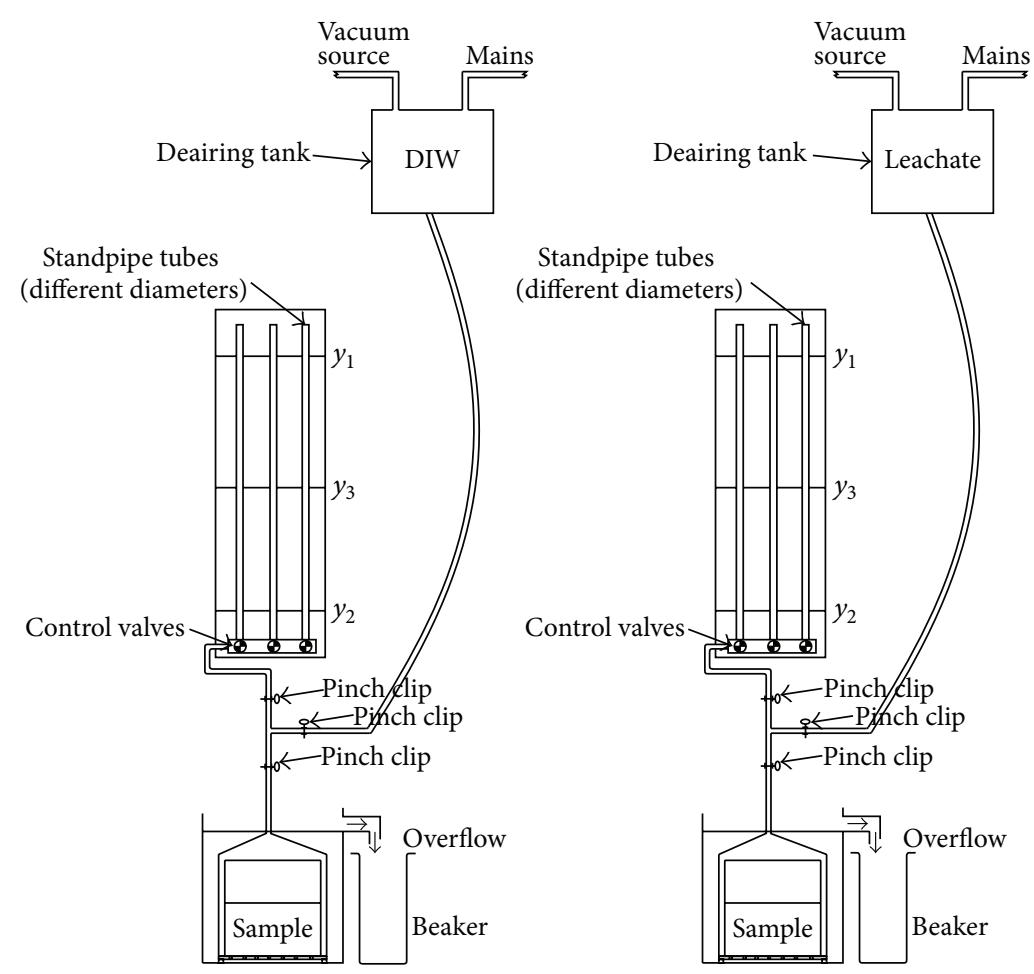

FIGURE 1: Experimental setup for determination of hydraulic conductivity.

prepared for determination of hydraulic conductivity. The hydraulic conductivities were computed using

$$
k=2.303 \frac{a L}{100 A t} \log _{10} \frac{y_{1}}{y_{2}},
$$

where $k$ is hydraulic conductivity $(\mathrm{m} / \mathrm{s}), a$ is area of standpipe tube $\left(\mathrm{m}^{2}\right), L$ is specimen disc thickness along the flow path $(\mathrm{m}), A$ is specimen disc cross-sectional area $\left(\mathrm{m}^{2}\right), t$ is elapsed time over which the flow occurs (s), $y_{1}$ is height of water above datum in standpipe at time $t_{1}(\mathrm{~m})$, and $y_{2}$ is height of water above datum in standpipe at time $t_{2}(\mathrm{~m})$.

\section{Results and Discussion}

4.1. Compaction Characteristics. The MDDs of compacted soil samples containing $5 \%, 10 \%, 15 \%$, and $20 \%$ IOT in comparison to the reference sample (soil with no addition of IOT) are presented in Figure 2. As can be seen from Figure 2, there is clear evidence that MDD of the soil-IOT mixtures compacted at the four compactive efforts increased almost linearly with increase in the percentage addition of IOT. In general, the MDD falls within a narrow range for each compactive effort: 1.75 to $1.82 \mathrm{Mg} / \mathrm{m}^{3}$ for RBSL, 1.77 to $1.83 \mathrm{Mg} / \mathrm{m}^{3}$ for BSL, 1.80 to $1.86 \mathrm{Mg} / \mathrm{m}^{3}$ for WAS, and 1.83 to $1.91 \mathrm{Mg} / \mathrm{m}^{3}$ for BSH. The MDD of the soil compacted with no addition of IOT ranged from 1.71 to $1.80 \mathrm{Mg} / \mathrm{m}^{3}$. In general soil specimens containing $20 \%$ IOT exhibit a pronounced improvement in mechanical properties leading to improvement in MDD for each compactive effort. The OMC results are plotted against IOT content as shown in Figure 3. As can

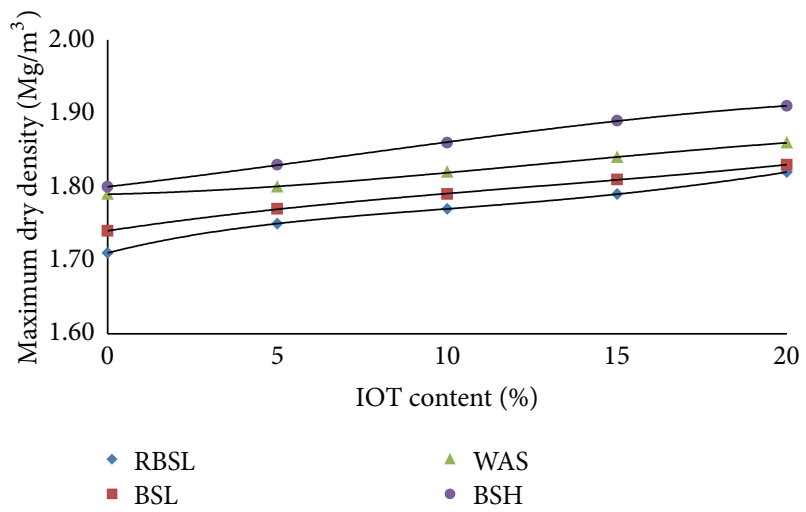

FIgURE 2: Maximum dry density versus iron ore tailings content for soil compacted using four types of compactive efforts.

be seen from Figure 3, the results exhibited general trends of decreasing OMC with increase in percentage addition of IOT. As expected, the OMCs decreased with increase in percentage of IOT and increased with increase in compactive effort. The OMC of the reference soil sample ranged from 14.7 to $16.4 \%$. In the case of soil-IOT mixtures, the OMCs also fall within a narrow range for each compactive effort: 13.0 to $15.3 \%$ for RBSL, 12.9 to $14.8 \%$ for BSL, 12.8 to $13.5 \%$ for WAS, and 12.2 to $13.8 \%$ for $\mathrm{BSH}$.

The results of this study are consistent with the findings of Abichou et al. [12] who reported a decrease in OMC and increase in MDD of foundry sand compacted at the reduced proctor, standard proctor, and modified proctor compactive efforts. Other investigators [21] also show an increase in MDD 


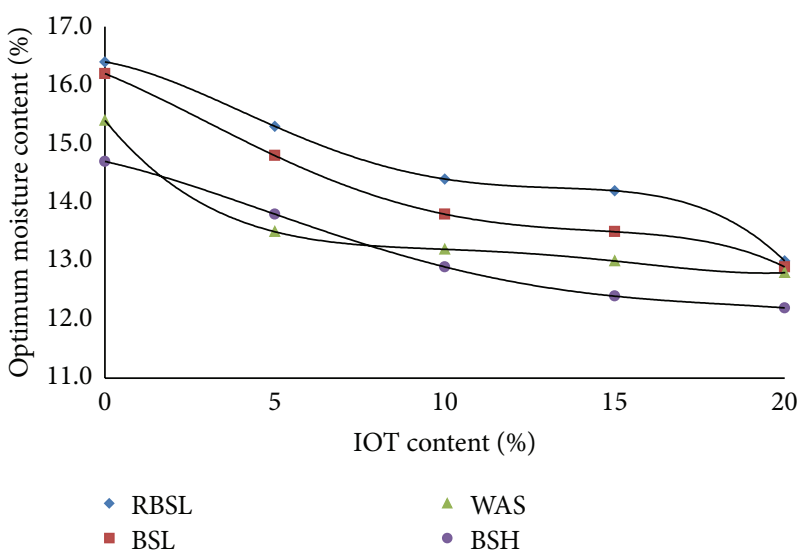

FIGURE 3: Optimum moisture content versus iron ore tailings content for soil compacted using four types of compactive efforts.

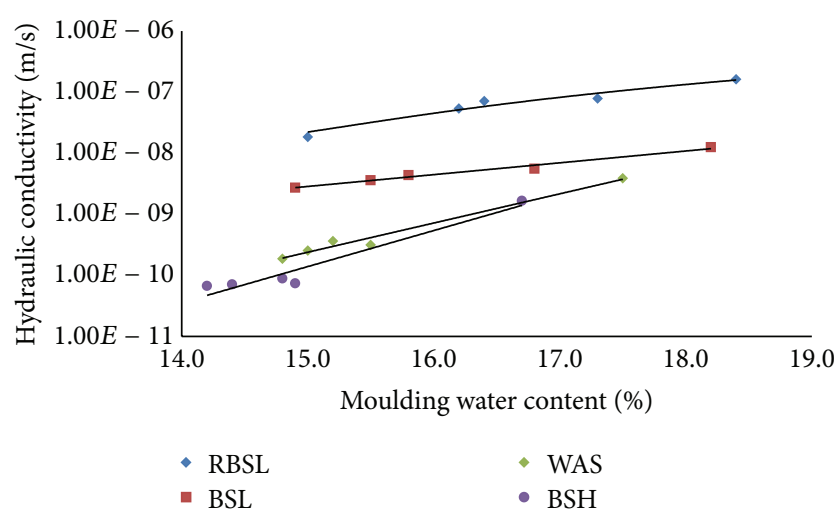

FIGURE 4: Hydraulic conductivity versus moulding water content for soil permeated with deionized water.

of lateritic soil-blast furnace slag mixtures with increase in percentage addition of blast furnace slag. The reason for the increase in the MDD and corresponding decrease in OMC of the soil investigated in this study with increase in IOT content was due to the low hygroscopic nature of IOT attributable to high concentration of ferric oxide $\left(\mathrm{Fe}_{2} \mathrm{O}_{3}\right)$. Furthermore, the treated soil produced heavier agglomerate particles with attendant rise in density leading to an increase in the overall surface area of the soil-IOT mixtures.

\subsection{Effect of Moulding Water Content on Hydraulic Conductiv-} ity. The variations of hydraulic conductivity with moulding water content for compacted soil specimen permeated with deionized water are shown in Figure 4. Soil with no addition of IOT exhibited hydraulic conductivities that are somewhat higher than the values obtained for soil-IOT mixtures. As was the case for the compaction test results, the hydraulic conductivity falls within a narrow range for each compactive effort: $1.7 \times 10^{-7}$ to $5.6 \times 10^{-8} \mathrm{~m} / \mathrm{s}$ for RBSL. However, soilIOT mixtures compacted at higher compaction energies (i.e., WAS and $\mathrm{BSH}$ ) yielded lower hydraulic conductivity values ranging from $2.6 \times 10^{-10}$ to $4.0 \times 10^{-9} \mathrm{~m} / \mathrm{s}$ and $7.2 \times 10^{-11}$ to $1.7 \times 10^{-9} \mathrm{~m} / \mathrm{s}$, respectively.

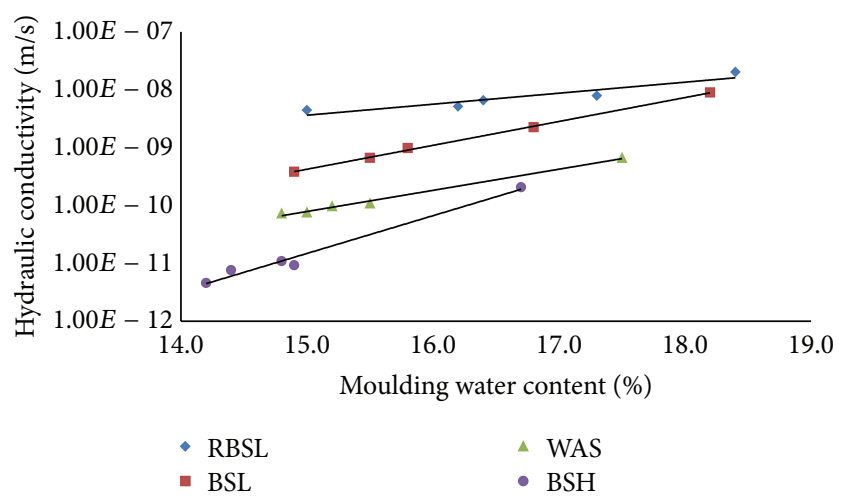

FIgURE 5: Hydraulic conductivity versus moulding water content for soil permeated with leachate.

The results of hydraulic conductivity of compacted soilIOT mixtures permeated with leachate are shown in Figure 5. As can be seen from Figure 5, permeation with leachate resulted in lower values of hydraulic conductivity when compared with deionized water permeation. Hydraulic conductivity generally increases with moulding water content and decreases with increase in compactive effort. The hydraulic conductivity ranged from $5.3 \times 10^{-9}$ to $2.1 \times 10^{-8} \mathrm{~m} / \mathrm{s}$ for RBSL, $6.8 \times 10^{-10} \mathrm{~m} / \mathrm{s}$ to $9.3 \times 10^{-9} \mathrm{~m} / \mathrm{s}$ for BSL, $7.7 \times 10^{-11} \mathrm{~m} / \mathrm{s}$ to $6.8 \times 10^{-10} \mathrm{~m} / \mathrm{s}$ for WAS, and $7.7 \times 10^{-12}$ to $1.1 \times 10^{-11} \mathrm{~m} / \mathrm{s}$ for $\mathrm{BSH}$. The moulding water content ranged from 14.4 to $18.7 \%$ for the four compactive efforts used.

The hydraulic conductivity results obtained in this study are, however, opposite to those reported by other authors $[12,21]$ who noticed a decrease in hydraulic conductivity of soil-additive mixtures with increase in moulding water content. Abichou et al. [12] reported a decrease in hydraulic conductivity with increase in moulding water content of compacted foundry sand. Similarly, Osinubi and Eberemu [21] reported that increasing compaction water content of lateritic soil-blast furnace slag mixtures leads to a decrease in hydraulic conductivity of the compacted soil specimens. Therefore, increasing the compaction water content of soilIOT mixtures by $2 \%$ wet of optimum moisture content was not beneficial in terms of reduction in hydraulic conductivity probably due to the moderate clay content in the soil. It is evident that soil-IOT mixtures can be compacted at OMC to achieve hydraulic conductivity less than or equal to $1 \times$ $10^{-9} \mathrm{~m} / \mathrm{s}$ particularly at higher compactive efforts. On the view point of economy, soil specimens containing IOT in the range of 10 to $20 \%$ IOT can be prepared with moulding water content ranging from 14.9 to $16.8 \%$ and compacted using the BSL compactive effort to achieve the maximum regulatory hydraulic conductivity for construction of hydraulic barrier system for containment of municipal solid waste.

4.3. Effect of Iron Ore Tailings on Hydraulic Conductivity. The variation of the results of hydraulic conductivity with IOT content of compacted soil specimens permeated with deionized water is shown in Figure 6. The addition of IOT to the soil resulted in lower values for the calculated average 
TABLE 6: Hydraulic performance of the soil at $20 \%$ iron ore tailings content.

\begin{tabular}{lcccc}
\hline \multirow{2}{*}{ Compactive effort } & Iron ore tailings (\%) & \multicolumn{2}{c}{ Hydraulic conductivity $(\mathrm{m} / \mathrm{s})$} & Hydraulic performance index (\%) \\
& & $k_{\text {DIW }}$ & $k_{\text {leachate }}$ & $7.6 \times 10^{-9}$ \\
RBSL & 20 & $1.9 \times 10^{-8}$ & $3.9 \times 10^{-10}$ & 86.1 \\
BSL & 20 & $2.8 \times 10^{-9}$ & $7.4 \times 10^{-11}$ & 61.1 \\
WAS & 20 & $1.9 \times 10^{-10}$ & $4.6 \times 10^{-12}$ & 93.2 \\
BSH & 20 & $6.8 \times 10^{-11}$ & & \\
\hline
\end{tabular}

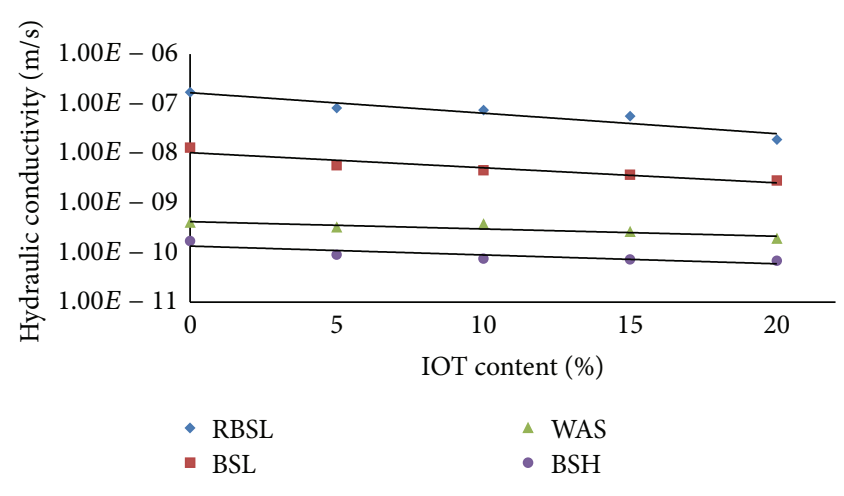

FIGURE 6: Hydraulic conductivity versus iron ore tailings content for compacted soil permeated with deionized water.

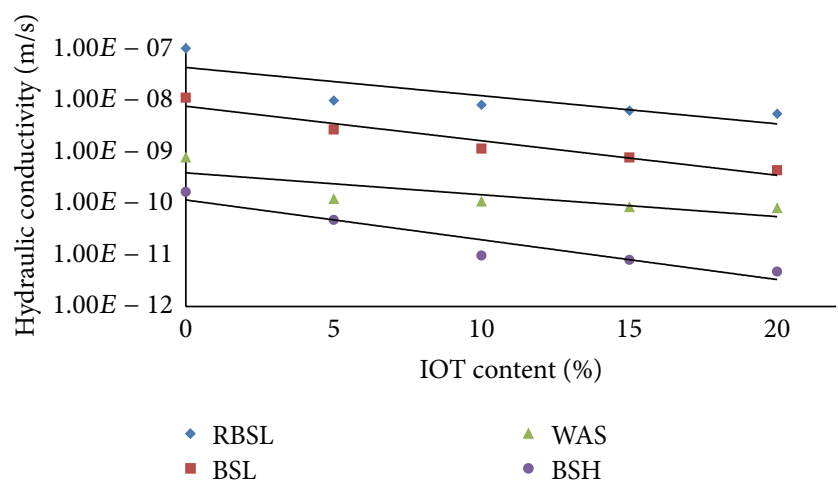

FIGURE 7: Hydraulic conductivity versus iron ore tailings content for compacted soil permeated with leachate.

hydraulic conductivity of the soil in comparison to the natural soil. Interestingly, hydraulic conductivity of the compacted soil-IOT mixtures decreased with increase in compactive effort. The results are consistent with those reported by Edil et al. [4] for compacted sand-fly ash mixtures. The authors reported that the variables, besides the compactive effort and moisture content, affecting hydraulic conductivity are the type and percentage of fly ash. Compacted soil treated with 5-20\% IOT yielded hydraulic conductivity values that are somewhat lower than those obtained for the natural soil.

The results of the hydraulic conductivity tests plotted against the percentage of IOT for compacted soil specimens permeated with leachate are shown in Figure 7. The trends in hydraulic conductivity are similar to those of soil specimens permeated with deionized water. The steady decrease in hydraulic conductivity with increasing IOT content was probably due to the high concentration of $\mathrm{Fe}_{2} \mathrm{O}_{3}$ in IOT which resulted in improvement in the mechanical properties of the soil. According to Shadfan et al. [22], the interaction of $\mathrm{Fe}_{2} \mathrm{O}_{3}$ with clay minerals depends on the environments' $\mathrm{pH}$. At low $\mathrm{pH}$, oxides precipitate on the surface of clay minerals and, once formed, these coatings are stable at high $\mathrm{pH}$ values. In cementation of the soil-IOT mixtures, $\mathrm{Fe}_{2} \mathrm{O}_{3}$ grows as crystals between the soil matrixes. These crystals' intergrowth resulted in very stable and nondispersible association between the soil matrixes [22].

The hydraulic conductivity results obtained based on permeation of the soil-IOT mixtures with leachate are consistent with the findings of Glatstein and Francisca [23] who reported negligible changes in hydraulic conductivity of silt-bentonite mixtures permeated with deionized water over time and observed a decrease in hydraulic conductivity when the permeant fluid was switched to nutrients solution. They reported that the nutrient loads present in the nutrients solution were responsible for increased formation and development of bacteria and yeast colonies resulting in partial or permanent pore blocking. Yeheyis et al. [24] also demonstrated a decrease in hydraulic conductivity of compacted soil-fly ash mixtures due to the precipitation of new minerals as a result of chemical interactions between acid mine drainage and fly ash.

4.4. Hydraulic Performance of Soil-Iron Ore Tailings Mixture. A comparison of the values of hydraulic conductivity determined from the experimental results based on permeation of the compacted soil-IOT mixtures with deionized water with its counterpart based on permeation with leachate is summarized in Table 6 . The results are somewhat similar but the hydraulic conductivity decreased with increase in compactive effort. Soil specimens containing 20\% IOT yielded the lowest hydraulic conductivity value of $4.6 \times 10^{-12} \mathrm{~m} / \mathrm{s}$. In terms of hydraulic performance, soil specimens treated with $20 \%$ IOT and compacted at the four compactive efforts yielded performance index values ranging from 61.1 to $93.2 \%$. The hydraulic performance of the soil-IOT mixtures was calculated using

$$
\text { Hydraulic performance index }(\%)=\frac{k_{\mathrm{DIW}}-k_{\text {leachate }}}{k_{\text {DIW }}},
$$

where $k_{\text {DIW }}$ is hydraulic conductivity of specimens permeated with deionized water $(\mathrm{m} / \mathrm{s})$ and $k_{\text {leachate }}$ is hydraulic conductivity of specimens permeated with leachate $(\mathrm{m} / \mathrm{s})$.

The performance of a barrier system component depends on the performance of the component itself and the way 
individual components interact as a system to contain contaminant transport. Takai et al. [25] stated that hydraulic conductivity of soil-bentonite mixtures has excellent correlation with their plasticity indexes and swelling pressures and concluded that these properties have some possibility to be indicators for estimation of hydraulic barrier performance of soil-bentonite mixtures.

\section{Conclusions}

(i) The silica-sesquioxide molar ratio of aluminum and iron for the soil was 1.21 suggesting that the soil is a laterite. Chemical compositions determined by the XRF spectroscopy revealed that the IOT conforms to ASTM C 618-15 Type F designation.

(ii) Soil specimens containing $20 \%$ IOT exhibit a pronounced improvement in mechanical properties leading to improvement in MDD for the four compactive efforts used. Economically, soil containing 20\% IOT can be compacted at moulding water content of $12.9 \%$ using the BSL compactive effort to achieve hydraulic conductivity less than or equal to $1 \times 10^{-9} \mathrm{~m} / \mathrm{s}$ and hydraulic performance of $86.1 \%$.

(iii) Increasing the compaction water content of soil-IOT mixtures by $2 \%$ wet of optimum moisture content was not beneficial in terms of improvement in hydraulic conductivity due to the moderate clay content in the soil.

(iv) Decreasing hydraulic conductivity with increase in percentage addition of IOT to the soil was due to the high concentration of $\mathrm{Fe}_{2} \mathrm{O}_{3}$ in IOT which leads to improvement in the mechanical properties of the soil.

(v) Soil-IOT mixtures permeated with leachate gave lower hydraulic conductivities when compared with deionized water permeation probably due to accumulation of biomass from bacteria and yeast which tends to significantly reduce the hydraulic conductivity and blocked up the soil pores.

(vi) Beneficial properties of IOT can be used in producing laterite soil with improved hydraulic properties which can be used as liner material for containment of municipal solid waste in hydraulic barrier system.

\section{Competing Interests}

The authors declare that there are no competing interests regarding the publication of this paper.

\section{References}

[1] M. E. Gordon, P. M. Huebner, P. Kimet et al., "An evaluation of the performance of four clay-lined landfills in Wisconsin," in Proceedings of the 7th Annual Madison Waste Conference, C. $\mathrm{H}$. Benson, Ed., pp. 399-460, University of Wisconsin-Madison, Madison, Wis, USA, 1994.

[2] D. E. Daniel, "Summary review of construction quality control for earthen liners, waste containment systems," in Construction,
Regulation, and Performance, R. Bonapate, Ed., vol. 26, pp. 175189, ASCE, New York, NY, USA, 1994, (in Benson et al. 1994).

[3] C. M. O. Nwaiwu, K. J. Osinubi, and J. O. Afolayan, "Statistical evaluation of the hydraulic conductivity of compacted lateritic soil," Geotechnical Testing Journal, vol. 28, no. 6, pp. 586-595, 2005.

[4] T. B. Edil, L. K. Sandstrom, and P. M. Berthouex, "Interaction of inorganic leachate with compacted pozzolanic fly ash," Journal of Geotechnical Engineering, vol. 118, no. 9, pp. 1410-1430, 1992.

[5] I. Borgadi, W. E. Kelly, and X. Wang, "Reliability model for soil liners," Journal of Geotechnical and Geoenvironmental Engineering, vol. 115, pp. 658-669, 1989.

[6] R. K. Rowe, R. M. Quigley, and J. R. Booker, Clayey Barrier Systems for Waste Disposal Facilities, E \& FN Spon, London, UK, 1995.

[7] D. E. Daniel, Geotechnical Practice for Waste Disposal, Chapman \& Hall, London, UK, 1993.

[8] K. J. Osinubi and C. M. O. Nwaiwu, "Desiccation-induced shrinkage in compacted lateritic soils," Geotechnical and Geological Engineering, vol. 26, no. 5, pp. 603-611, 2008.

[9] M. Yellishetty and G. M. Mudd, "Substance flow analysis of steel and long term sustainability of iron ore resources in Australia, Brazil, China and India," Journal of Cleaner Production, vol. 84, no. 1, pp. 400-410, 2014.

[10] M. Yellishetty, V. Karpe, E. H. Reddy, K. N. Subhash, and P. G. Ranjith, "Reuse of iron ore mineral wastes in civil engineering constructions: a case study," Resources, Conservation and Recycling, vol. 52, no. 11, pp. 1283-1289, 2008.

[11] B. W. Freber, "Beneficial reuse of selected foundry waste material," in Proceedings of the 19th International Madison Waste Conference, pp. 246-257, Department of Engineering Professional Development, University of Wisconsin, September 1996.

[12] T. Abichou, C. H. Benson, and T. B. Edil, "Foundry green sands as hydraulic barriers: laboratory study," Journal of Geotechnical and Geoenvironmental Engineering, vol. 126, no. 12, pp. 1174$1183,2000$.

[13] G. Moses and J. O. Afolayan, "Compacted foundry sand treated with cement kiln dust as hydraulic barrier material," Electronic Journal of Geotechnical Engineering, vol. 16, pp. 347-355, 2011.

[14] S. Y. Umar, A. U. Elinwa, and D. S. Matawal, "Hydraulic conductivity of compacted lateritic soil replaced with metakaolin," Journal of Environmental and Earth Science, vol. 5, pp. 53-64, 2015.

[15] AASHTO M145-91, Standard Specifications for Classification of Soils and Soil-aggregate Mixtures for Highway Construction Purposes, American Association of State Highway and Transportation Officials, Washington, Wash, USA, 1991.

[16] ASTM D2487-11, Standard Practice for Classification of Soils for Engineering Purposes (Unified Soil Classification System), ASTM International, West Conshohocken, Pa, USA, 2011.

[17] S. Y. Umar and A. U. Elinwa, "Effects of iron ore tailings and lime on engineering properties of problem laterite," Journal of Raw Materials Research, vol. 2, pp. 56-66, 2005.

[18] ASTM C618-15, Standard Specification for Coal Fly Ash and Raw Calcined Natural Pozzolan for Use in Concrete, ASTM International, West Conshohocken, Pa, USA, 2015.

[19] K. H. Head, Manual of Soil Laboratory Testing: Soil Classification and Compaction Tests, vol. 1, Pentech Press, London, UK, 1992.

[20] US EPA, "Requirements for hazardous waste landfills, design, construction and closure," Tech. Rep. EPA-125/4-89. 022, EPA, Cincinnati, Ohio, USA, 1989. 
[21] K. J. Osinubi and A. O. Eberemu, "Hydraulic conductivity of lateritic soil treated with blast furnace slag," Electronic Journal of Geotechnical Engineering D, vol. 11, pp. 1-16, 2006.

[22] H. Shadfan, J. B. Dixon, and L. A. Kippenber, "Palygorskite distribution in tertiary limestone and associated soil of northern jordan," Soil Science, vol. 140, no. 3, pp. 206-212, 1985.

[23] D. A. Glatstein and F. M. Francisca, "Hydraulic conductivity of compacted soils controlled by microbial activity," Environmental Technology, vol. 35, no. 15, pp. 1886-1892, 2014.

[24] M. B. Yeheyis, J. Q. Shang, and E. K. Yanful, "Feasibility of using coal fly ash for mine waste containment," Journal of Environmental Engineering, vol. 136, no. 7, pp. 682-690, 2010.

[25] A. Takai, T. Inui, T. Katsumi, M. Kamon, and S. Araki, "Factors affecting the hydraulic performance of soil-bentonite mixture cut-off wall," Journal of Japan Society of Civil Engineers (Geosphere Engineering), vol. 68, pp. 1-14, 2012. 


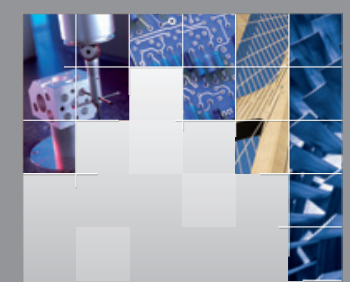

\section{Enfincering}
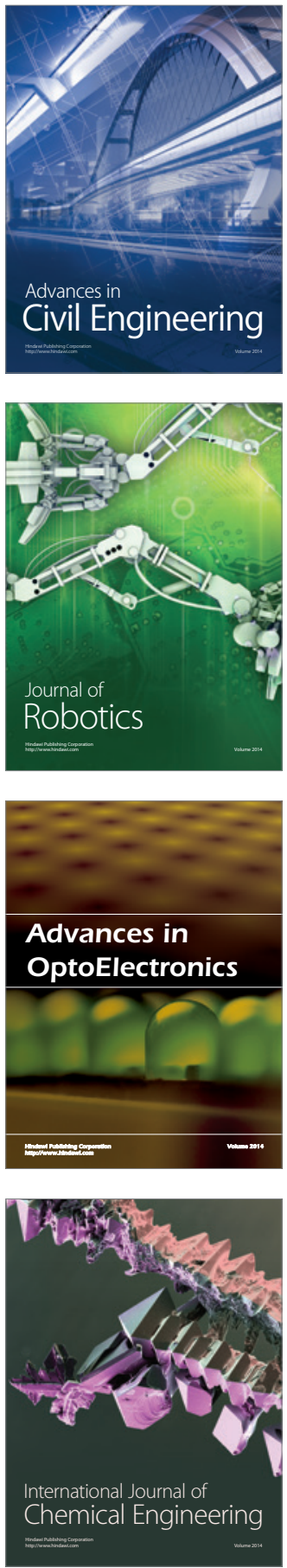

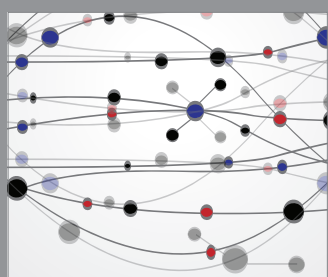

The Scientific World Journal

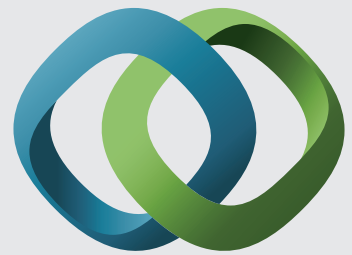

\section{Hindawi}

Submit your manuscripts at

http://www.hindawi.com
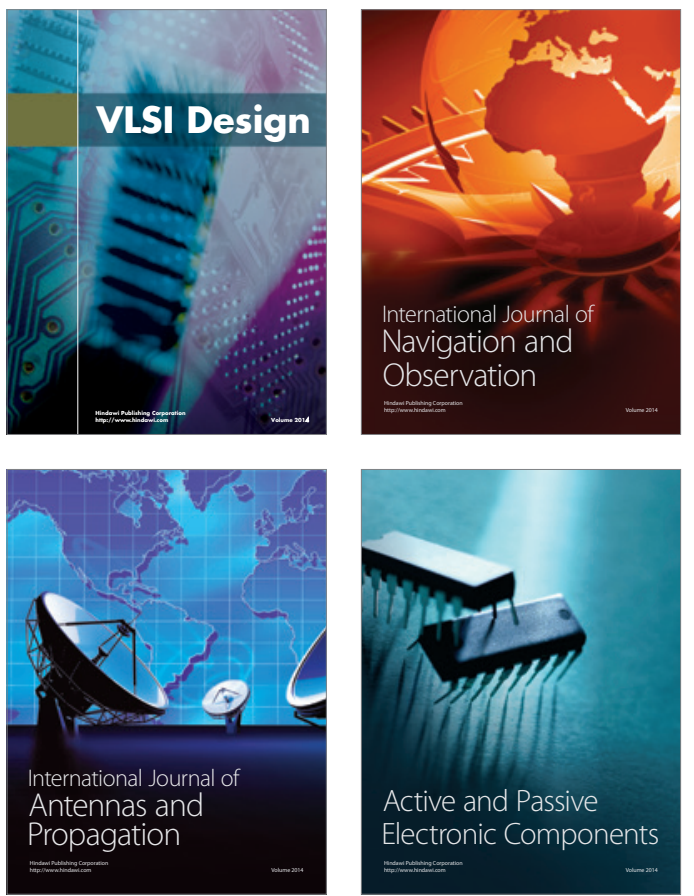
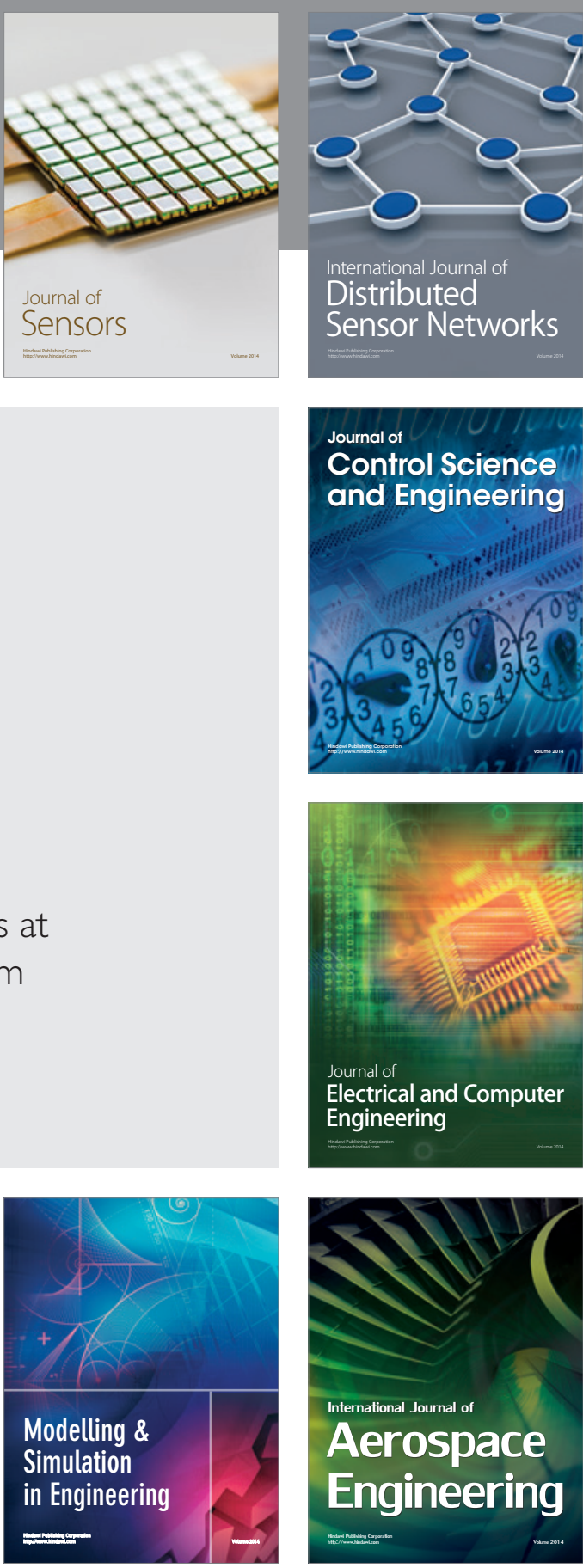

International Journal of

Distributed

Sensor Networks

Journal of

Control Science

and Engineering
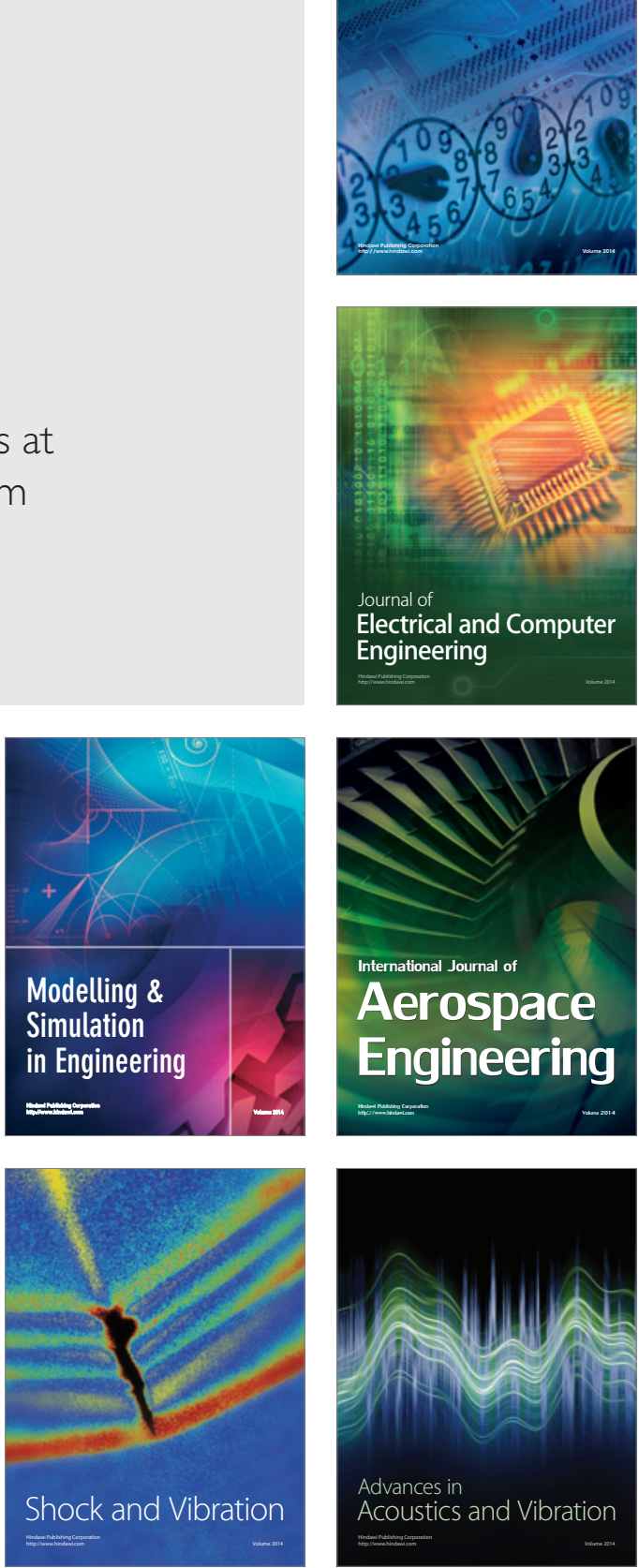